for the softer components of the radiation. In a recent communication to the Physical Review (Sept. 1, 1932) he concludes that there is a definite correlation between the intensity of the cosmic rays and the direction and magnitude of the earth's magnetic field. The intensity in general is higher the greater the angle of magnetic dip. The dependence of the intensity of the cosmic rays on magnetic latitude has also been convincingly shown by Clay and Berlage from continuous observations on a voyage from Amsterdam to Batavia.

Such a relation between intensity of the rays and the earth's magnetic field is to be expected on general grounds if the radiation consists of a stream of swift charged particles. It will be remembered that Prof. C. T. R. Wilson long ago suggested that the cosmic radiation may originate from thunderstorms in our atmosphere. In the intense electrical fields that precede a lightning flash, it is probable that electrons and other charged particles may acquire a very high velocity. If some of these pass out into space, their paths will be bent by the earth's magnetic field and a few may eventually re-enter our atmosphere. In the light of the new observations, such a possible origin of the cosmic radiations should not be overlooked. In this connexion, it should be noted that Schonland in South Africa has found that the intensity of the rays is suddenly altered by the occurrence of distant lightning flashes, but no such effect is observed immediately beneath the thundercloud.

The question of the nature of the cosmic rays is still a matter of much discussion--whether, for example, the primary radiation is of the $\gamma$-ray type or consists of a stream of fast electrons or protons-but there seems to be a growing belief that the main part of the radiation is corpuscular in character. This question is now being actively investigated by photographing the tracks of the ionising particles in an expansion chamber and observing the curvature of these tracks due to a strong magnetic field. By this method Millikan and Anderson have found that not only are swift electrons present, but also positively charged particles believed to be swift protons. Many of these particles undoubtedly have energies corresponding to several hundred million electron volts. Blackett and Occhialini (NATURE, Sept. 3, 1932) have made experiments of a similar kind using an ingenious device whereby the passage of an ionising particle through two Geiger counters in line is made to actuate an expansion chamber, placed between the counters, within a hundredth of a second of the passage of the radiation. By this device the accumulation of data should be much more rapid. By the full use of these powerful methods, we may hope soon to obtain definite information as to the nature and energy of these ionising particles, and of the effects produced by them in their passage through matter.

Reference should also be made to another strange type of occurrence observed with the cosmic rays. Hoffmann and Steinke and Schindler have observed sudden bursts of ionisation in a measuring vessel, of a magnitude far exceeding that produced by the swiftest $\alpha$-particle known. It has been suggested that these bursts of ionisation arise from some type of disintegration process brought about by the cosmic rays: whatever may be the explanation, there can be no doubt these observations suggest a fascinating if difficult field for further research. It should be mentioned that Compton, in his recent experiments already referred to, noted that these bursts of ionisation are much more frequent at high altitudes, and suggested that they may be due mainly to an effect of the softer components of the radiation.

The problem of the origin and the nature and properties of the cosmic rays is one of the most interesting in the domain of physics. It is to be hoped that the concentrated attack from so many different directions will soon bring more definiteness to our knowledge of this obscure type of radiation.

\title{
Obituary
}

Mr. Winliam G. Collingwood

$\mathrm{T}$ $\mathrm{HE}$ death of William Gershom Collingwood, artist, archæologist and author, at the age of seventy-eight years, took place at Coniston on Oct. 1. The son of a well-known landscape painter, W. Collingwood, he was born at Liverpool on Aug. 6, 1854, and matriculated at University College, Oxford, in 1872. While at Oxford, where he took first class honours in Literae Humaniores, he formed a close friendship with Ruskin, then Slade professor, and when the health of the latter broke down, accompanied him abroad to France and Italy, later settling near him at Windermere. Here he occupied himself in landscape painting, editing Ruskin's works and lecturing on the theory and history of art. After Ruskin's death he was for some time professor of art at the University of Reading.
In Cumberland Collingwood had come into contact with members of the Cumberland and Westmoreland Antiquarian Society and had been attracted to the study of Icelandic literature and the archæology of the Norse settlements in the north of England. The first fruits of his studies, however, took the form of fiction, his first novel appearing after a visit to Iceland in 1897. Illdirected criticism of his second venture "The Bondwoman", notwithstanding its high literary merit, diverted him to a more intensive study of the Norse and Anglian archæology of northern England, especially on its artistic side, upon which he became widely recognised as the first authority. A long series of papers in the Proceedings of the Antiquarian Society, of which he became editor, culminated in the publication of an exhaustive and

No. 3285, Vol. 130] 
standard work on "Northumbrian Crosses" (1927), in which a knowledge both wide and profound was combined with keen insight and artistic feeling. Although to the general public "The Life and Work of John Ruskin" among Collingwood's writings will be his strongest claim to remembrance, "Northumberland Crosses" is his most enduring achievement. Under his editorship the Proceedings of the Cumberland and Westmoreland Antiquarian Society attained a standard of technical and artistic excellence unusual among the publications of local scientific societies; and he was the inspiration and the organiser of much of the excellent work in archæological research which has been accomplished by the Society in the present century. In 1920 his work was recognised by election to the presidential chair.

\section{Mr. H. C. Chadwick}

We regret to announce the death of Mr. Herbert Clifton Chadwick on Sept. 16 at the age of seventythree years. He was the last survivor of a group of scientific men who, in the 'eighties of the last century, began the biological investigation of the Irish Sea region. For this purpose the late Sir William Herdman founded the Biological Station at Port Erin, in the Isle of Man, and Mr. H. C. Chadwick, then a business man in Manchester and an amateur naturalist, was made curator of the laboratories. He was a recognised authority on the morphology and systematics of the Echinodermata and was the author of many papers on these subjects. But his general zoological knowledge was very wide and in his capacity of curator of the Port Erin Station he was able to assist very many investigators and students who worked there during the last forty years.

WE regret to announce the following deaths:

Prof. Karl E. Ritter von Goebel, For. Mem. R.S., professor of botany in the University and Director of the Botanical Gardens, Munich, an authority on cryptogamic botany, especially Bryophyta and ferns, on October 10, aged seventyseven years.

Dr. T. H. C. Stevenson, formerly superintendent of statistics at the General Register Office, who rendered great service in the field of vital statistics, on September 12, aged sixty-two years.

Prof. William Stirling, formerly Brackenbury professor of physiology in the University of Manchester and in 1906-9 Fullerian professor of physiology at the Royal Institution, on October 1 , aged eighty-one years.

Dr. Florence A. Stoney, formerly demonstrator in anatomy at the London School of Medicine for Women, who was a pioneer in X-ray and ultraviolet light treatment, on October 7 , aged sixtytwo years.

Sir Everard Im Thurn, K.B.E., formerly curator of the British Guiana Museum, and in 1919-20 president of the Royal Anthropological Institute, on October 8, aged eighty years.

\section{News and Views}

\section{Antony van Leeuwenhoek, I632-1723}

ON October 24, 1632, four days after the birth of Sir Christopher Wren at East Knoyle, Wiltshire, the tercentenary of which has just been celebrated, Antony van Leeuwenhoek, the eminent Dutch naturalist who has been called the "Father of Protozoology and Bacteriology" was born at Delft. Both Wren and Leeuwenhoek were long associated with the Royal Society in its early days, and both lived to extreme old age; Leeuwenhoek outliving Wren by six months and dying at Delft on August 26, 1723, being then aged-as his epitaph says-"90 years, 10 months, and 2 days". But the careers of these two distinguished men followed very different lines; for while Wren was first a professor of astronomy and then a great architect, Leeuwenhoek began his life as a draper and haberdasher with few advantages of education, and his fame came through his lifelong devotion to microscopical studies. The son of a basket maker, he was sent to a school at Warmond, near Leyden, and at sixteen was an apprentice in Amsterdam. At the age of twenty-two years he married and set up in business for himself in his native town, and for thirty-nine years was "Chamberlain of the Council-Chamber of the Worshipful sheriffs of Delft". He was also a surveyor and wine gauger. When he began his work with his simple microscopes is not known, but at the age of forty-one years he addressed the first of his many letters to the Royal Society, then eager to get into touch with all men working for "the promotion of natural knowledge", and it was through these letters he became famous. He was made a fellow of the Royal Society in 1679 (1680 N.S.), a correspondant of the Paris Academy of Sciences in 1699, and in 1716 the University of Louvain presented him with a medal. At his death at Delft in 1723 he was buried in the Old Church, in which his daughter Maria, in 1739, erected a monument to his memory.

\section{Leeuwenhoek and the Royal Society}

THE connexion of Leeuwenhoek with the Royal Society was unique, since, although for fifty years he was a constant correspondent and for forty-three years a fellow, he never attended a single meeting. His letters were all written in old-fashioned Dutch and before publication in the Transactions were translated into English or Latin. They were none the less highly appreciated and many distinguished men visited Delft in order to see the writer of them. $\mathrm{He}$, indeed, became one of the 'sights' of the pleasant town. In spite of his wonderful discoveries and his communications to the Royal Society, hitherto there has been no good account of his career in English.

$$
\text { No. 3285, VoL. 130] }
$$

